struggling economy. Current law requires the state to cut greenhousegas emissions by $25 \%$ on 1990 levels by 2020, and the California Air Resources Board is bringing in regulations to make that happen, including a cap-and-trade system that would allow businesses to decide where to make emissions reductions. California has long led the United States on environmental policy, and this is exactly the kind of action that will expand and could, in time, pave the way for a more comprehensive approach on climate in Washington DC.

California has already been joined by seven other states in the country's west, and four Canadian provinces, in the Western Climate Initiative. Farther east, six states and one Canadian province have signed the Midwestern Greenhouse Gas Reduction Accord. These two programmes aim to cut greenhouse-gas emissions by $15 \%$ and $20 \%$, respectively, on 2005 levels by 2020. Carbon trading has already begun under the first such programme, the Regional Greenhouse Gas Initiative, under which ten northeastern states have committed to reducing current levels of emissions by $10 \%$ by 2018 .

In total, 23 US states and five Canadian provinces have begun their own climate initiatives, independent of their countries' federal governments. The Washington DC-based World Resources Institute calculates that these initiatives cover half the US population and one-third of its greenhouse-gas emissions. In Canada, the numbers are even more impressive: more than three-quarters of the population and half the greenhouse-gas emissions are covered. Twenty-eight states have standards on renewable energy, and countless other efforts are under way that would encourage energy savings and greenhouse-gas reductions at the state and local level.

And do not count out the federal government just yet. The

administration of President Barack Obama is preparing to roll out new greenhouse-gas regulations next year and has a variety of other tools at its disposal. The administration has ordered the federal government, the largest energy consumer in the nation, to reduce emissions by $28 \%$ on 2008 levels by 2020 . The federal government - and the defence department in particular - also has enormous purchasing power. If used wisely, that could help drive green technologies to market.

Clearly, these limited efforts are not sufficient. Concerned citizens

"As policy labs of long standing, US states can demonstrate the power of 'bottom-up' leadership." in the United States and around the world are right to be disappointed in the lack of leadership and vision in Congress. Barring a sharp reversal on their campaign rhetoric, it seems that the situation will only get worse when Republicans take control of the House of Representatives next year. But many of these Republicans hail from those states that are quietly embarking on their own programmes to combat global warming. These aren't just feel-good measures, either. They are confidence builders.

It's possible that, globally, climate change is simply too complex a problem for a comprehensive top-down solution. There are too many interests at stake, too many losers with loud voices. And although most Americans clearly accept the reality of global warming, most people simply don't care that much, particularly when economic woes loom large. That's not a recipe for success in the power corridors of Washington. But California and other US states are policy labs of long standing, and as such will continue to demonstrate the power of 'bottom-up' leadership.

\section{Worth waiting for}

\section{A wise report on genetic screening from the Leopoldina has been 350 years in the making.}

\section{$\mathrm{T}$} This week, the Leopoldina, Germany's national academy of sciences in Halle, is due to publish a historic report. The publication analyses how advances will affect the field of predictive genetic diagnosis, and calls for changes in a law that has confused science and ideology. It is also notable for being the first report to come from the Leopoldina in its role as a national academy - three and a half centuries after it was set up.

The law, which came into force in February, had been debated for nearly a decade. The legislation was intended to protect the population from the possible abuse of genetics, but instead presents an unreasonable threat to the health of individuals with treatable genetic disorders.

One problem is that the law ranks patient confidentiality above a doctor's responsibility to the health of that patient's relatives. It rules, for example, that genetic data collected for diagnosis should be destroyed after ten years, even though the guidelines of the German Chamber of Physicians say that such data should be retained for at least 30 years to provide for the health of the next generation. The law also misunderstands details of science. To name but one instance, it redefines neonatal screening for genetic disease - used routinely for decades to identify 12 treatable genetic disorders by chemical, not DNA, analysis - as 'genetic screening. This means that a doctor with expertise in genetic counselling, rather than a midwife, must take blood for the test. This complicates processes, and in small rural hospitals where such expertise is not available some doctors are reportedly simply choosing not to screen.

These problems have their roots in a cultural fear of sharing medical data - a legacy of the Nazi era. With Germany's federalized health-care system, patients can move between doctors of their choosing without any of their medical history following them. This situation makes it impossible to carry out optimal population screening for genetic diseases, and will restrict the future health value of new technologies.

The Leopoldina, too, is embroiled in the legacies of history - and has seen a lot of history flow past since it was founded as a scientific academy in 1652. In 2007, federal research minister Annette Schavan unilaterally declared that the Leopoldina would become Germany's national academy. In doing so, she put an end to years of acrimonious debate about which, if any, of the country's seven regional academies should be elevated to this status. That ruffled feathers. Germany's federal structure was designed as a core element of its 1949 constitution, to prevent any centralization of power and thus to ensure that a fascist regime could never take control again. Individual states were given wide powers and have inevitably become protective of them. All this left Germany without a national academy to provide, among other things, authoritative and independent scientific advice for policymaking. With its first report, the Leopoldina has already shown the value of such an institution.

The academy established a committee of 17 scientists and legal experts to analyse how new genomic technologies and other advances are set to affect predictive genetic diagnosis, and how Germany can better prepare itself for the opportunities and ethical challenges that will follow. The resulting report, Predictive Genetic Diagnostics as an Instrument of Disease Prevention, calls for the creation of national centres of competence to overcome these barriers. There are legal hurdles to this, but they can, and should, be overcome.

The Leopoldina's report responds to a shadow of history. Politicians should follow its recommendations and change the law to prevent further damage. It is time for Germany to see its past in the appropriate historical context, and to ensure that its psychological legacies do $\rightarrow$ NATURE.COM To comment online, click on Editorials at: go.nature.com/xhunqu not inadvertently harm the innocent today. And the Leopoldina? From its base in what was once an important centre of chemical industry in the former East Germany, it will be able to direct a little bit of history, not just watch it flow by. 